\title{
Temperature Effect due to Internal Reforming in Pressurized SOFC
}

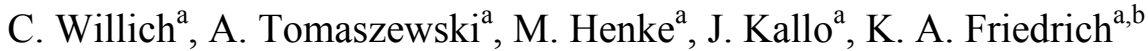 \\ ${ }^{a}$ German Aerospace Center (DLR), Institute of Technical Thermodynamics, \\ Pfaffenwaldring 38-40, 70569 Stuttgart, Germany \\ ${ }^{\mathrm{b}}$ University of Stuttgart, Institute of Thermodynamics and Thermal Engineering, \\ Pfaffenwaldring 6, 70550 Stuttgart, Germany
}

\begin{abstract}
For the integration in a hybrid power plant the behavior of pressurized SOFC stacks was examined. A detailed electrochemical model was validated allowing for a thorough interpretation of experimental data. This contribution focuses on the use of reformate gases and the influence of internal reforming. Experimental and simulated current-voltage characteristics and electrochemical impedance spectra were used to examine the temperature differences due to internal reforming which were found to have a major impact on performance. It is shown that similar performance can be obtained for different fuel gas compositions if temperature within the stack is controlled.
\end{abstract}

\section{Introduction}

Since the demand for electrical energy is growing continually power plants with high efficiency and low emissions are needed for the future. A hybrid power plant consisting of an SOFC system combined with a gas turbine is a promising solution since it offers electrical efficiencies of over $60 \%$ (1) at a wide power range of applications from $\mathrm{kW}$ to MW. A further advantage of such a combined system is that it can be operated amongst others on natural gas available from the existing grid. For building a demonstration power plant and ensuring a stable operation of such a system it is necessary to know how each subsystem is behaving under the given conditions.

The planned demonstration hybrid power plant will be operated with natural gas as fuel, therefore the operation with reformates is of immense interest. The SOFC will be operated at elevated pressures since efficiencies have been shown to be highest with a direct coupling of SOFC and gas turbine (2). Therefore, experiments and modeling of pressurized solid oxide fuel cell stacks (PSOFC) were carried out with various fuels and the effects of pressurization on open circuit voltage (OCV), power density and fuel gas composition were examined (3). These previous experiments on pressurized solid oxide fuel cells have shown a significant increase in performance at elevated pressures (4). This increase is attributed to the pressure dependency of diffusion, activation effects at both electrodes and an increase in Nernst potential.

For this contribution the effect of internal reforming of methane on the temperature and the performance of the stack was examined through a combined modeling and experimental approach. Simulations using a previously validated detailed electrochemical model (5) were used to examine temperature changes within the stack for different fuels. 
Experimental impedance spectroscopy allows for a thorough examination of various resistances due to different mechanisms at the cell. It was used to determine the ohmic resistance of the cell, which in turn can be used to determine stack temperature.

\section{Experimental}

In the pressurized SOFC test rig at DLR SOFC short stacks can be characterized at pressures of 1 to 8 bar. Pressure difference between anode and cathode gas compartments and the furnace can be controlled by a pressure control system up to 500 mbar. This pressure control is important to keep pressure differences low since a large pressure difference may lead to the destruction of the cells or stack. The maximum temperature for testing is $950{ }^{\circ} \mathrm{C}$ and the stack in the test rig can be supplied with mixtures of hydrogen, nitrogen, methane, carbon monoxide, carbon dioxide and steam on the anode side that can be mixed to represent reformate gases. At the cathode air, oxygen, nitrogen and helium are available. The test rig offers the possibility to measure current-voltage characteristics of the stack and its individual cells as well as performing impedance spectroscopy on the cells. The gas composition at the in- and outlet of the anode and cathode can be measured by means of a gas chromatograph (3).

For the results presented in this contribution anode-supported 5-cell short stacks with an active area of $84 \mathrm{~cm}^{2}$ per cell were used. They consist of sintered cells which are brazed into stamped metal sheet bipolar plates as shown in Figure Figure 1. These are referred to as cassettes. The cells consist of an anode substrate (Ni/YSZ) and functional layer. The YSZ electrolyte is $10 \mu \mathrm{m}$ thick and the cathode consists of two layers, a functional layer made of LSM/YSZ and a current collector made of LSM.

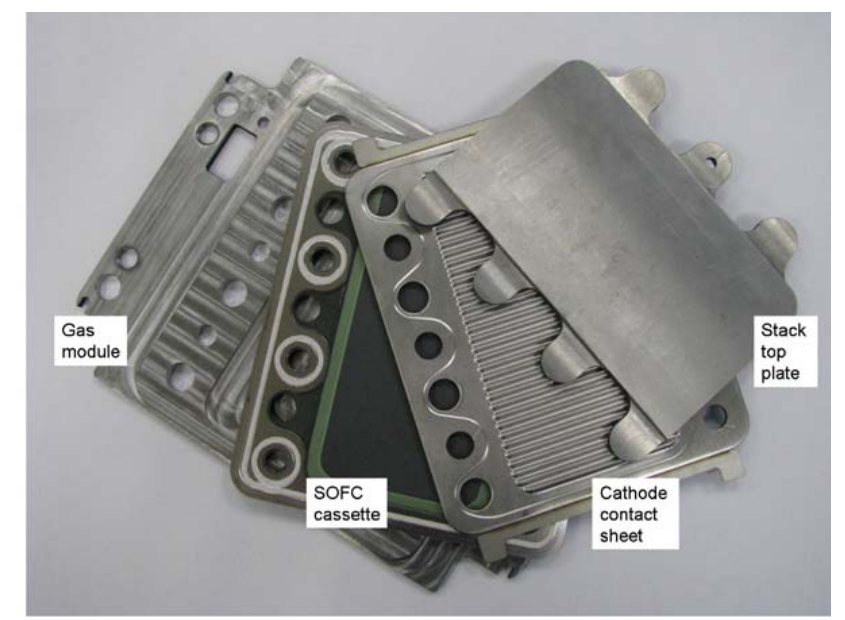

Figure 1: Cell integrated into metal bipolar plates.

Measurements were done with three different fuels. For reference a $\mathrm{H}_{2} / \mathrm{N}_{2}$ mixture containing $48.5 \% \mathrm{H}_{2}, 48.5 \% \mathrm{~N}_{2}$ and $3 \%$ of water was used and two different reformates, one a partially reformed reformate containing $18 \% \mathrm{H}_{2}, 34 \% \mathrm{H}_{2} \mathrm{O}, 2 \% \mathrm{CO}, 27 \% \mathrm{CO}_{2}$ and $19 \% \mathrm{CH}_{4}$ (reformate 1) and a reformate containing $58.4 \% \mathrm{H}_{2}, 20 \% \mathrm{H}_{2} \mathrm{O}, 12.2 \% \mathrm{CO}$, $5.5 \% \mathrm{CO}_{2}$ and $3.9 \% \mathrm{CH}_{4}$ (reformate 2) (3). The latter (reformate 2) corresponds to a mixture of methane and water with a steam to carbon ratio of 2 that is completely 
prereformed at 4 bar and $750{ }^{\circ} \mathrm{C}$ and therefore in chemical equilibrium at these conditions. The flow rate for the $\mathrm{H}_{2} / \mathrm{N}_{2}$ mixture was $10 \mathrm{l} / \mathrm{min}$ and the flow rates for the two reformates were chosen to obtain the same theoretical current resulting in a total flow rate of $5.06 \mathrm{1} / \mathrm{min}$ for reformate 1 and $5.63 \mathrm{l} / \mathrm{min}$ for reformate 2 . The cathode gas was air. Pressure was varied between 1.35 and 8 bar while keeping pressure differences between anode, cathode and the surrounding pressure vessel small. The stack was operated inside a furnace and all gases were preheated to furnace temperature before the stack inlet. Results shown in this work are for one of the inner cells of the stack.

\section{Simulations}

Simulations of the stack were done using a multi-scale model which is based on an in-house software (6). The model represents in detail the electrochemical reactions on the surface of the electrodes, the gas transport within the porous electrodes and in the gas channels on cell level and the thermal coupling of five adjacent cells to include temperature-related effects on stack level. The model was validated in a wide range of operating conditions with current-voltage characteristics and impedance measurements (5). An elementary kinetic mechanism for steam reforming and water-gas shift in the Nibased anode taken from Janardhanan et al. (7) is included in the model.

The model can now be used to better understand the processes at the cell and how they are influenced. It can also be used to asses the influence of parameters that cannot be measured directly with the used setup like the temperatures inside the stack at the cell.

\section{Results}

Figure 2 shows the simulated (lines) and measured (symbols) current-voltage curves for reformate 1 (left) and reformate 2 (right) for one cell in the middle of the stack as well as the simulated temperatures within the stack (dotted line) at different pressures. It can be seen that the measured and simulated current-voltage characteristics show a good agreement for both reformates at all pressures. If the simulated temperature is regarded, it can be seen that the temperatures at OCV differ with pressure, which can be explained by a different degree of reforming for different pressures and therefore a different gas composition (3). A different degree of reforming leads to a difference in cooling of the cell due to the endothermic reforming reaction.

The temperatures at OCV also differ for the two reformates. While for reformate 1 the temperature at $\mathrm{OCV}$ is between $750{ }^{\circ} \mathrm{C}$ and $770{ }^{\circ} \mathrm{C}$ it is between $790{ }^{\circ} \mathrm{C}$ and $801{ }^{\circ} \mathrm{C}$ for reformate two. It can also be seen from figure 1 that the current densities reached for reformate 1 are lower than for reformate 2 . In the following it will be examined to what extent this difference in performance is due to the difference in temperature. 

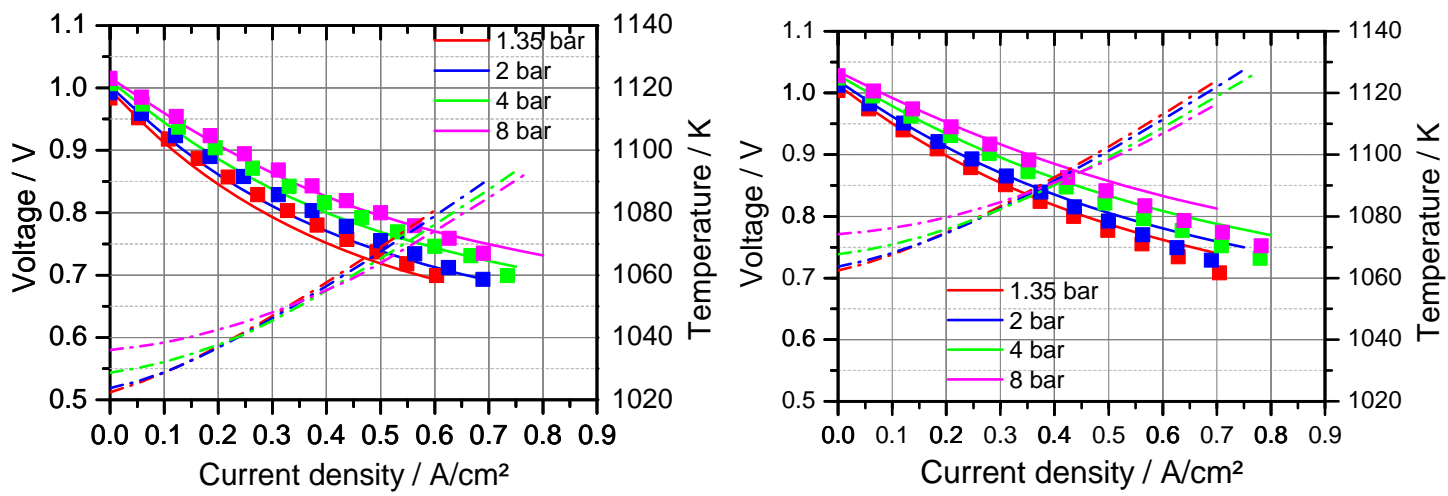

Figure 2: Simulated (lines) and measured (symbols) current voltage curves for reformate 1 (left) and reformate 2 (right) for one cell in the middle of the stack and simulated temperatures within the stack (dotted line) at different pressures.

\section{$\underline{\text { Temperature Effect }}$}

In Figure 3 simulated and measured current-voltage curves for $\mathrm{H}_{2} / \mathrm{N}_{2}$ and reformate 1 are shown at a constant furnace temperature of $750{ }^{\circ} \mathrm{C}$. As is to be expected the stack reaches a higher open circuit voltage when operated with hydrogen/nitrogen than during operation with the reformate and the performance under reformate conditions is considerably lower over the entire range of the polarization curve. Figure 3 also shows the simulated temperature at the cell. It can be seen that the cell temperature at OCV is lower for the reformate gas than for the $\mathrm{H}_{2} / \mathrm{N}_{2}$ mixture. Operation of the stack with a reformate gas mixture containing unreformed methane leads to internal reforming reactions on the cell and since these are endothermic to a temperature decrease within the stack. It was previously shown in (3) that the gas composition is in equilibrium after the cell.

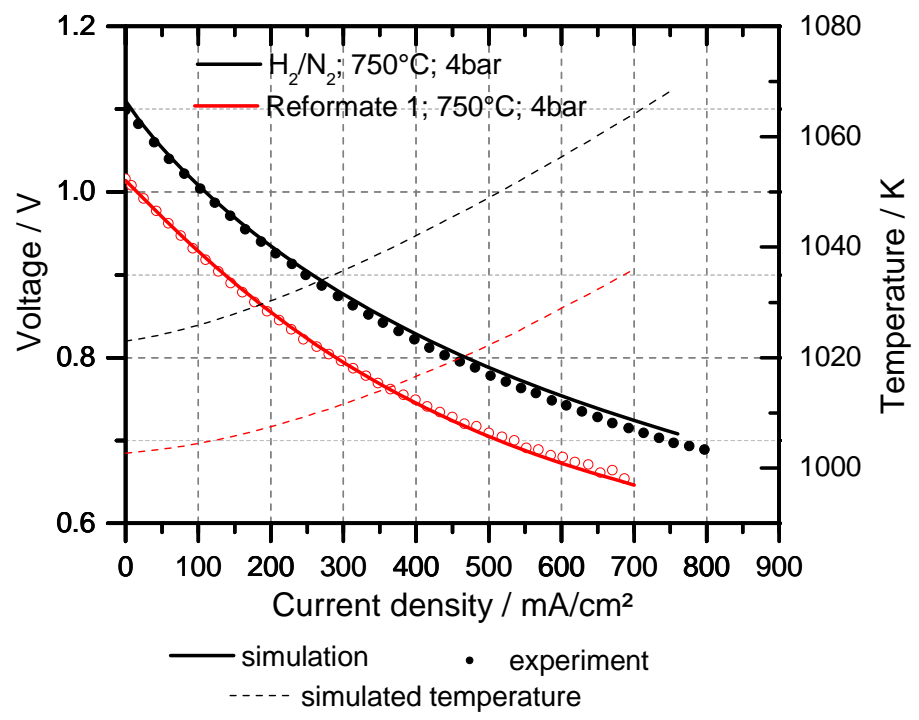

Figure 3: Simulated (lines) and measured (symbols) current voltage curves for $\mathrm{H}_{2} / \mathrm{N}_{2}$ and reformate 1 for one cell at $750{ }^{\circ} \mathrm{C}$ furnace temperature and 4 bar. 
In the used setup a direct measurement of the temperature within the stack was not possible, therefore electrochemical impedance spectra (EIS) were used to asses the temperature effect. Via EIS it is possible to determine the ohmic resistance $R_{\Omega}$ of the setup, which in turn is temperature dependent. At different temperatures different ohmic resistances will result from the impedance spectra. If the same ohmic resistance is obtained the temperature within the stack can be assumed to be the same.

Figure 4 shows the temperature dependence of experimental impedance measurements at high frequencies between $700{ }^{\circ} \mathrm{C}$ and $750{ }^{\circ} \mathrm{C}$ with hydrogen and nitrogen as fuel. The ohmic resistance of the cell $(\operatorname{Re} Z$ at $\operatorname{Im} Z=0)$ is clearly temperature dependent with the ohmic resistance being lowest for highest temperatures. If the cell is operated with the $\mathrm{H}_{2} / \mathrm{N}_{2}$ gas mixture no reforming reactions take place inside the cell and neglecting leakages it can be assumed that in this case the temperature inside the stack at $\mathrm{OCV}$ is equal to the furnace temperature.

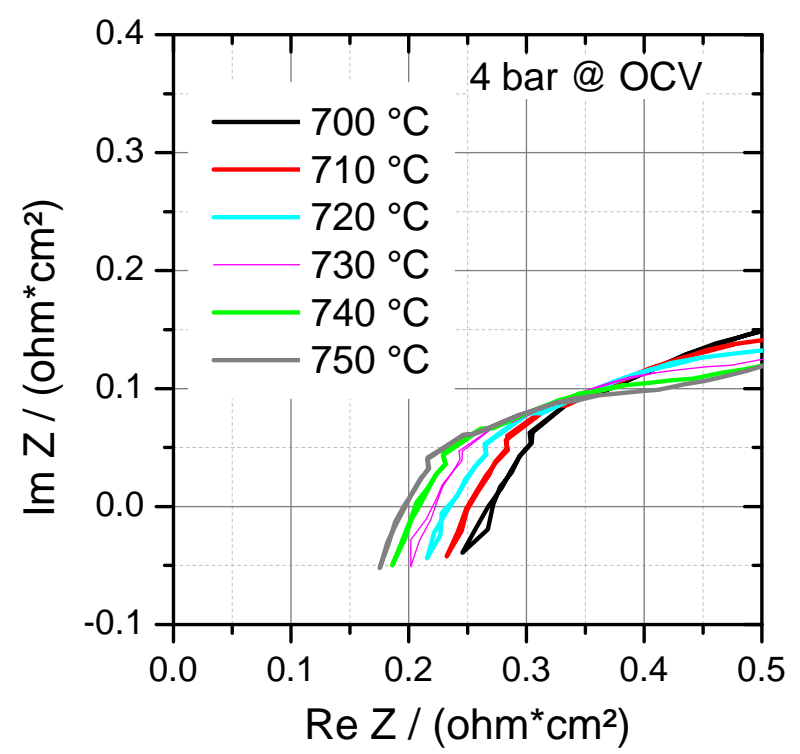

Figure 4: Measured electrochemical impedance spectra for one cell at OCV and 4 bar with $\mathrm{H}_{2} / \mathrm{N}_{2}$ gas mixture at temperatures between 700 and $750{ }^{\circ} \mathrm{C}$.

In order to assess the temperature differences within the stack between operation with $\mathrm{H}_{2} / \mathrm{N}_{2}$ and with reformate 1 , impedance measurements at $\mathrm{OCV}$ and $750{ }^{\circ} \mathrm{C}$ furnace temperature were performed for both gases. The results can be seen in Figure 5. Although the furnace temperature was $750{ }^{\circ} \mathrm{C}$ for both gas mixtures, the results show a difference in ohmic resistance. The higher ohmic resistance of the reformate measurement means that the temperature within the stack is lower due to internal endothermic reforming reactions which are cooling the stack.

In order to achieve comparable temperatures within the stack, the furnace temperature was increased in the experiments to $785{ }^{\circ} \mathrm{C}$ for the reformate mixture resulting in equal ohmic resistances and thus equal cell temperature for both gas mixtures. The result of the impedance measurements and the ohmic resistance are also given in Figure 5. 


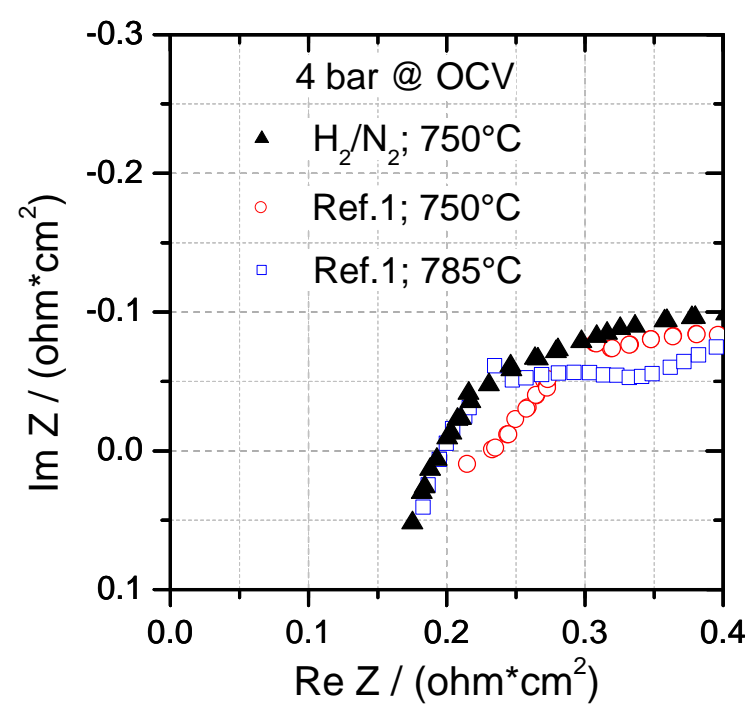

Figure 5: EIS detail of high frequency range - comparison of ohmic resistance at OCV and pressure of 4 bar of $\mathrm{H}_{2} / \mathrm{N}_{2}$ at $750{ }^{\circ} \mathrm{C}$ and reformate 1 at $750{ }^{\circ} \mathrm{C}$ and $785{ }^{\circ} \mathrm{C}$

After the furnace temperature adjustment to $785^{\circ} \mathrm{C}$, the experimental reformate $V(\mathrm{i})$ curve draws closer to the $\mathrm{H}_{2} / \mathrm{N}_{2}$ curve at higher current densities as shown in Figure 6. The curves for the $\mathrm{H}_{2} / \mathrm{N}_{2}$ mixture and the reformate still differ strongly at $\mathrm{OCV}$ as that is only slightly affected by the change in temperature. Under load the difference between the two curves diminishes and at higher current density the difference between the two curves is only a few millivolts..

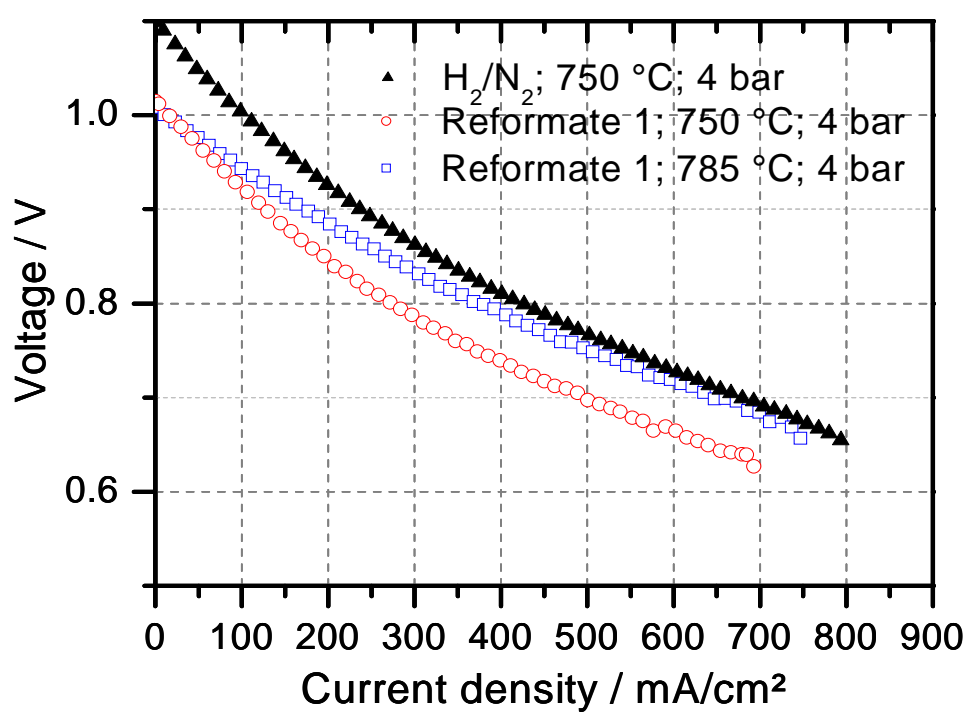

Figure 6: Measured current voltage curves for $\mathrm{H}_{2} / \mathrm{N}_{2}$ (triangle symbols) and reformate 1 (circle symbols) of the stack at $750{ }^{\circ} \mathrm{C}$ and 4 bar and reformate 1 at $785^{\circ} \mathrm{C}$ (square symbols). 


\section{Temperature Effect in the Model}

For the experiments an increase in furnace temperature of $35^{\circ} \mathrm{C}$ to $785^{\circ} \mathrm{C}$ was necessary according to Figure 5 to obtain the same ohmic resistance and therefore the same temperature within the stack. In the model an increase to $780{ }^{\circ} \mathrm{C}$ is necessary to obtain the same temperature within the stack as shown in Figure 7.

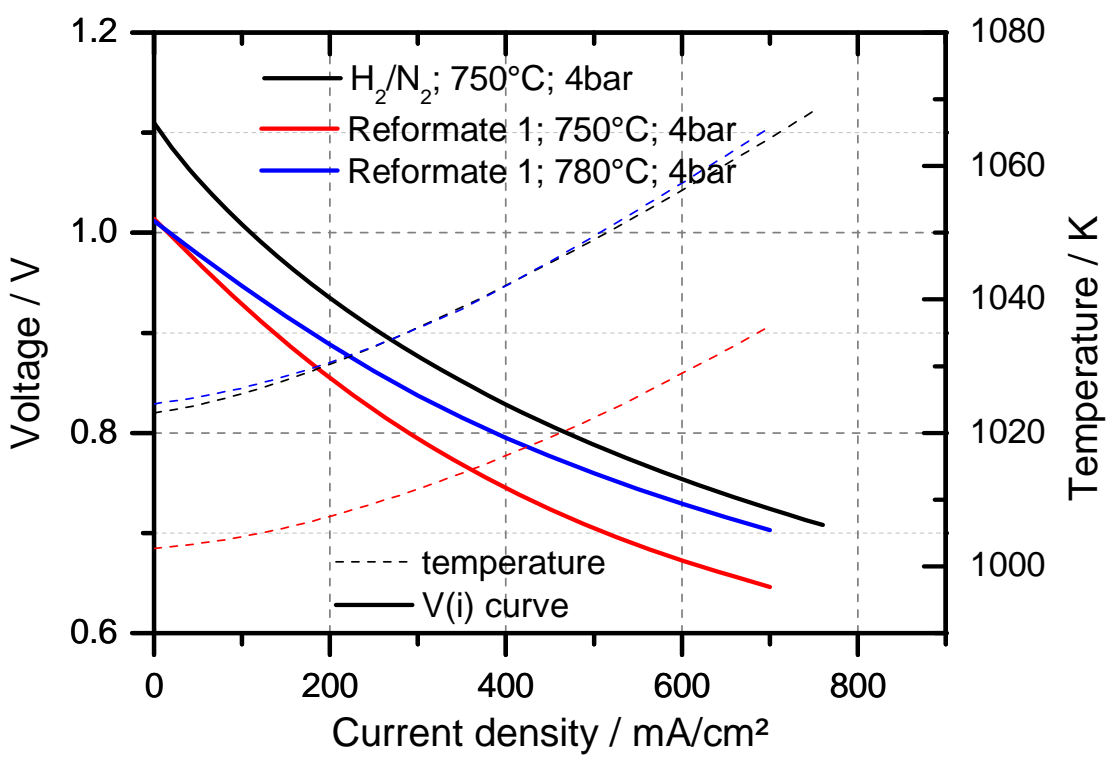

Figure 7: Simulated $V(\mathrm{i})$ curves and temperatures for $\mathrm{H}_{2} / \mathrm{N}_{2}$ and reformate 1 at different furnace temperatures.

There is a difference of about $5 \mathrm{~K}$ between the simulated temperatures and the temperature differences determined by EIS but experiment and simulation show the same tendency and the agreement is satisfactory.

\section{Various Degrees of Prereforming}

In Figure 7 the simulated current-voltage characteristics and temperatures (dotted lines) for three different reformates at constant furnace temperature of $800{ }^{\circ} \mathrm{C}$ and $4 \mathrm{bar}$ are shown. The fuel gases are the two reformates described above and a third fuel composition (reformate 3 ) which is a methane/water mixture with a steam to carbon ratio of 2 like reformate 2 , the $\mathrm{C} / \mathrm{H} / \mathrm{O}$ ratio is the same, but only half of it is prereformed. It therefore contains a larger amount of unreformed methane and more internal reforming is necessary in the stack. In Figure 7 three fuel gases lead to different performances and temperatures inside the stack if the furnace temperature is constant. 


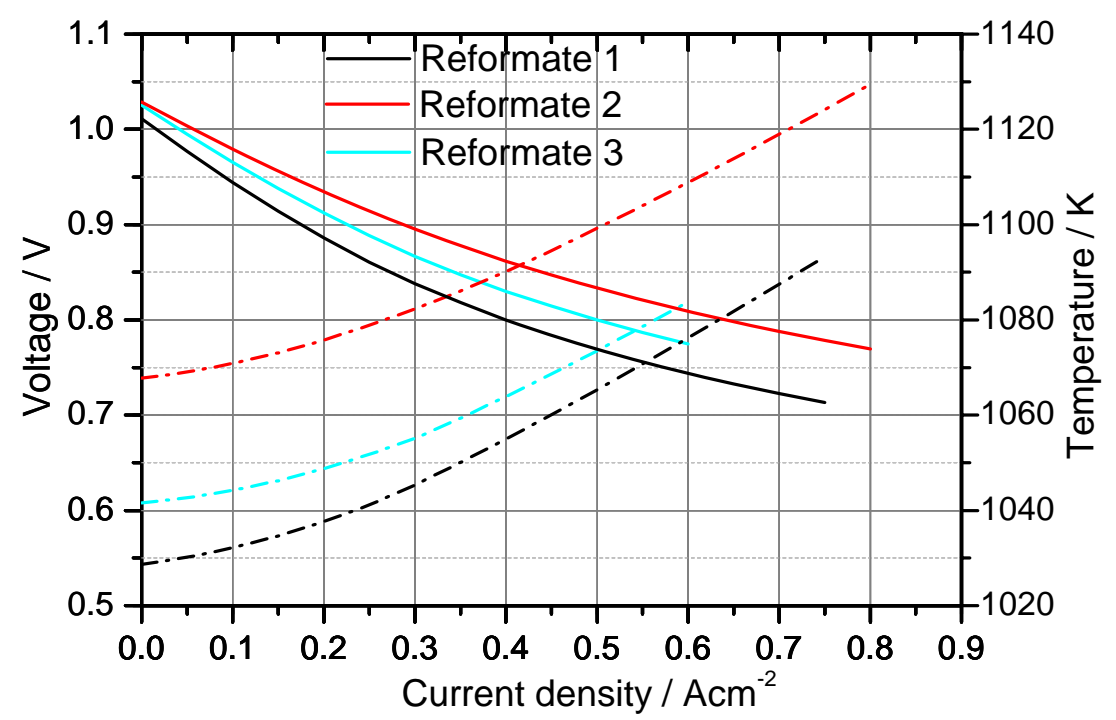

Figure 7: Simulated current-voltage characteristics and temperature (dotted lines) for three different reformate compositions at a constant furnace temperature of $800{ }^{\circ} \mathrm{C}$ at 4 bar.

Figure 8 shows simulated current-voltage curves and temperatures for the same reformate fuel gases as Figure 7, but here the temperature was adjusted so that the stack temperature at OCV is the same for all three gases. It can be seen that now there is no difference between the prereformed and only partially prereformed methane/water mixture, neither in the current-voltage curve nor in the temperature. The difference in performance as observed in Figure 7 was therefore entirely due to the temperature difference and it can be stated that it is not the large amount of unreformed methane in itself which is responsible for a weaker performance but only the temperature difference which is induced by the internal reforming reaction.

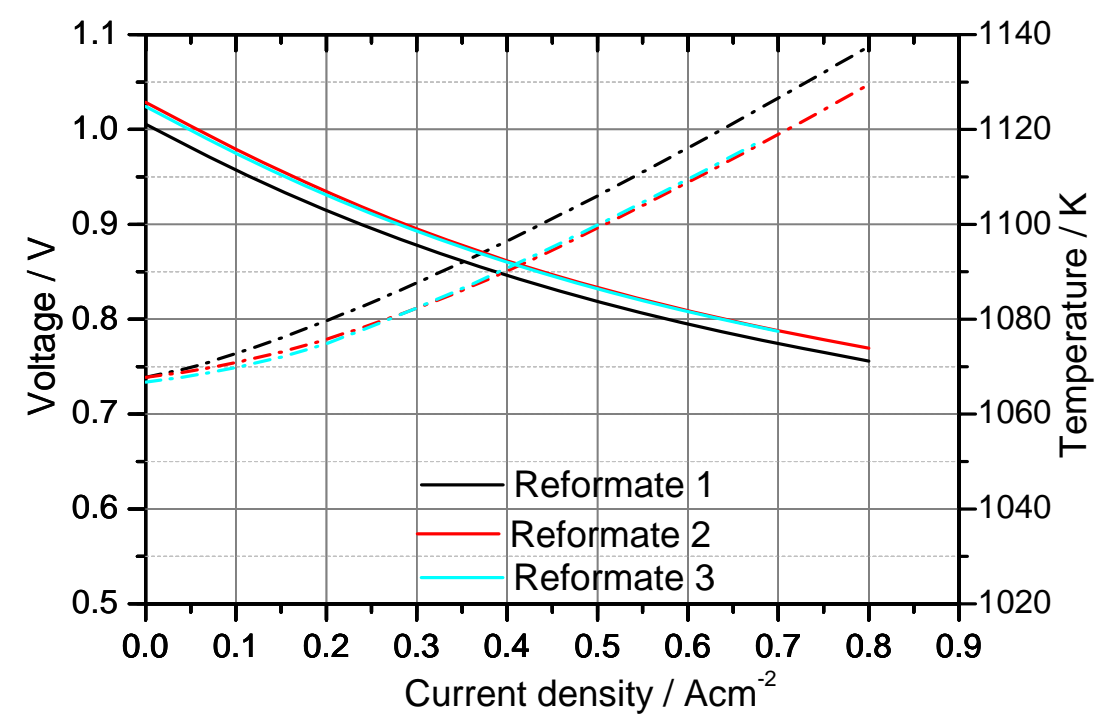

Figure 8: Simulated current voltage characteristics and temperature (dotted lines) for three different reformate compositions with the same stack temperature at OCV at 4 bar. 
As already seen, the performance for reformate 1 also increases for the adapted temperature. Nevertheless the current voltage curve remains slightly below that of the other reformate. Only this difference which can be seen in figure 8 is really due to the different gas composition.

\section{Conclusions}

Measurements with reformate fuels were performed at various pressures and used to validate a model that was then used to asses the cooling effect due to internal reforming within the stack. The cooling effect was also examined experimentally using EIS. It was found that a larger methane content leads to a lower performance of the cell only because internal reforming lowers the temperature in the stack. Even for different $\mathrm{C} / \mathrm{H} / \mathrm{O}$ ratios a large part of the difference in performance is due to temperature and only to a small extent to gas composition.

For operation of SOFC systems using fuel gases containing hydrocarbons like the hybrid power plant, these results show that similar performance results can be obtained for different fuels if the temperature within the stack is controlled. A complete prereforming of the fuel is not necessary to obtain the same performance. Partly unreformed fuel can be fed to the SOFC at higher temperature and similar performance can be expected at current densities relevant for SOFC systems.

\section{Acknowledgments}

The authors would like to acknowledge the funding supplied by DLR and the German Federal Ministry of Economics and Technology (BMWi).

\section{References}

1. S. Singhal and K. Kendall, High Temperature Solid Oxide Fuel Cells Fundamentals, Design and Application, Elsevier, Oxford, pp. 374 (2003).

2. T. Panne, A.Widenhorn, J. Boyde, D. Matha, V. Abel, and M. Aigner, "Thermodynamic Process Analyses of SOFC/GT Hybrid Cycles," in 5th International Energy Conversion Engineering Conference and Exhibit, St. Luis, Missouri (2007).

3. C. Willich, C. Westner, M. Henke, F. Leucht, J. Kallo, W.G. Bessler, U. Maier, and K.A. Friedrich, "Pressurized Solid Oxide Fuel Cells with Reformate as Fuel", J. Electrochemical Society 159 (11), F711-F716 (2012).

4. M. Henke, C. Willich, C. Westner, F. Leucht, R. Leibinger, J. Kallo, and K.A. Friedrich, "Effect of Pressure Variation on Power Density and Efficiency of Solid Oxide Fuel Cells" Electrochimica Acta 66, p.158-163 (2012).

5. M. Henke, C. Willich, C. Westner, F. Leucht, J. Kallo, W. G. Bessler, and K. A. Friedrich, Fuel Cells, submitted.

6. W. G. Bessler S. Gewies, and M. Vogler, A new framework for physically based modeling of solid oxide fuel cells, Electrochimica Acta 53, p. 1782-1800, (2007).

7. V. M. Janardhanan and O. Deutschmann, Journal of Power Sources, 162, 11921202 (2006). 